ELORE (ISSN 1456-3010), vol. 17 - 2/2010.

Julkaisija: Suomen Kansantietouden Tutkijain Seura ry.

[http://www.elore.fi/arkisto/2_10/herranen_2_10.pdf]

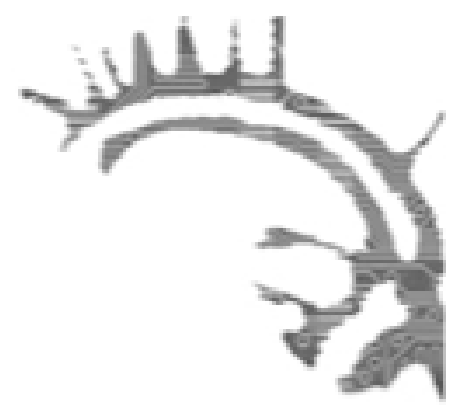

\title{
MENETELMÄT MONITIETEELLISEN TUTKIMUKSEN HAASTEENA
}

\author{
Liisa Granbom-Herranen
}

Pääsääntöisesti jokaisella tieteenalalla on omat kiinnostuksen kohteensa, tutkimusmenetelmänsä sekä terminologiansa. Tutkimuksen sijoittuessa aihepiiriltään useamman tieteenalan puitteisiin, on luontevaa lähestyä ongelmaa hyödyntäen näitä tutkimustraditioita. Käytän tässä esimerkkinä kasvatustieteen väitöskirjaani "Sananlaskut kasvatuspuheessa - perinnettä, kasvatusta, indoktrinaatiota?” vuodelta 2008. Sananlaskututkimus on siinä sekä teoreettisesti että menetelmällisesti varsin keskeisessä asemassa.

\section{TUTKIMUKSEN LÄHTÖKOHDAT}

Keskeisin tutkimustehtävä on ollut tarkastella sananlaskujen vaikuttavuutta kasvatuksessa. Tämä vaikuttavuus voi olla joko positiivista tai negatiivista. Oppimis- ja kasvatuskäsityksen perusoletus on arkioppimisessa. Tieteenaloja yhdistävä tekijä on arkinen lasten kasvatus eli se kuinka lapset ovat kasvaneet ja kasvattuneet aikana, jolloin yhteiskunta ei yleisen oppivelvollisuuskoulun kautta vielä vaikuttanut lapsen elämään. Olen pyrkinyt tavoittamaan puhutun muistitiedon aikaa suomenkielisen rahvaan keskuudessa. 1800 luvulla ja 1900-luvun alussa suomenkielinen rahvas muodosti kansan enemmistön. Puhuessani rahvaasta tarkoitan sitä osaa väestöstä, joka koostui ensisijaisesti maaseudun tilattomasta väestöstä ja johon katsotaan kuuluvaksi myös kaupunkien palkolliset ja muu työväestö. Tarkemmin rahvaan määrittelyn perusteista löytyy esimerkkinä olevasta väitöskirjasta (ks. Granbom-Herranen 2008, 16, 111-112).

Tiedon perustana on muistelijoiden oma kokemus elämismaailmastaan, mikä tosin aina muodostuu vuorovaikutuksessa ympäristön kanssa - yksilöllinen kokemus toteutuu yhteisön kanssa jaetussa tilassa. Ilmiö ja sen merkitys voidaan tavoittaa vain kokemuksen kautta (Satulehto 1992, 60). Elämäntarinoissa käsitellään muistelijoi- 
den kokemuksia ja heidän niille antamiaan merkityksiä. Objektiivista todellisuutta ei ole, vaan ihminen luo oman todellisuutensa. Samoin tieto perustuu ihmisen kokemukseen ja ymmärrykseen. Merkitykset voivat muuttua ja laajentua, niiden tulkinta elää. Heijastuessaan ympäristöön annetut merkitykset muokkaavat sekä yksilön omaa kokemusta että yhteisön käsityksiä. (Perttula 1993, 268.) Tämä käsitys todellisuudesta on ohjannut varsinaisen tutkimusmenetelmän ja tutkimuksellisen lähestymistavan valintaa. Siirryttäessä tilassa (aikakaudessa tai kulttuurisessa paikassa) ei tietoa voi jakaa oikeaan ja väärään. Keskeiseksi muodostuu pyrkimys löytää tutkimuksen kysymyksenasettelun kannalta kohteen ymmärtävä ja sille oikeutta tekevä lähestymistapa. (Kalela 2000, 25.)

Tutkimukseni tulosten yleistettävyys perustuu siihen, että on olemassa yksi maailma, joka kuitenkin ilmenee ihmisten kokemuksissa eri tavoin. Yksilöllisen, ainutlaatuisen elämismaailman ja tutkimuksen johtopäätösten yleistettävyyden välillä ei muodostu ristiriitaa, onhan yksilön maailma muokkautunut yhteisön keskuudessa. Tässä ajan ja paikan luomassa tilassa, vallinneessa sosiokulttuurisessa ja yhteisöllisessä todellisuudessa on kehys, jonka puitteissa yksilöllisyys mahdollistuu. (Perttula 1993, 272.) Liitettäessä ihmisten käsityksiä yhteen voidaan muodostaa kuva yhteisesti koetusta todellisuudesta, sillä yksilön tekemä tulkinta, hänen tapansa antaa ilmiölle merkityksiä, on harvoin sattumanvarainen, vaan sitä ohjaavat yhteisön hyväksymät näkemykset. (Uljens 1989, 20.) Kuvaukset eivät luo täydellistä kuvaa ilmiöstä eikä yhteisestä todellisuudesta. Ihmisten käsityksiä todellisuudesta ei voi verrata keskenään. Yhden ihmisen käsitykset eivät voi olla toisen käsityksiä todellisempia, parempia tai oikeampia. Käsityksiä ei voi myöskään verrata johonkin todellisuuteen, sillä todellisuus muodostuu niistä käsityksistä, joita ihmisillä todellisuudesta on.

Kielenkäytössäni käsite sananlasku kattaa myös viittaukset sananlaskuihin toisin kuin esimerkiksi Matti Kuusen $(1954,7)$ määrittelyssä. Aineistoa tarkastellessani en olisi toiminut muistelijoiden ajattelua kunnioittaen, mikäli olisin päätynyt Kuusen jaottelun kaltaiseen tulkintaan. (ks. Granbom-Herranen 2008, 37-38). Kasvatuspuheen sananlaskuineen olen rajannut suomenkieliseen kerrontaan ja siten suomenkieliseen väestöön. Tätä kielellistä rajausta pidän välttämättömänä kahdesta syystä. Ensinnäkin puheen ja erityisesti sananlaskujen ymmärtäminen edellyttää kielen ja kulttuurisen kontekstin haltuunottoa. Käännökset ovat aina jollakin tavoin tulkintoja. Rajaus on mielekäs käsitellessäni suomenkielisen muistelukerronnan sisältämiä suomenkielisiä sananlaskuja. Toiseksi, koska sananlaskut säilyvät varsin muuttumattomina sukupolvelta toiselle, palautuu 1900 luvun alun kasvatuspuhe sääty-yhteiskunnan aikaan, jolloin suomenkieli oli rahvaan kieli. Tarkastelemaani suomenkielisen väestön kokemusmaailmaa voidaan pitää enemmistön elämismaailmana, ruotsinkielisten osuus rahvaasta on ollut pieni (Granbom-Herranen 2008, 39). Suomenkieli ei ollut valtaa pitävien kieli, vaan arjen kieli, joka jakaantui paikallisiin murteisiin. Toisistaan poikkeavien elämismaailmojen lisäksi rahvaan ja eliitin välistä vuorovaikutusta vähensi puhuttujen kielten erilaisuus.

Tarkasteluni kohteena ovat lapsuusmuistojen kasvatuspuheeseen sisältyneet sananlaskut. Muistelijoiden lapsuus sijoittuu 1900-luvun alun ja toisen maailmansodan väliseen aikaan. Koska sananlaskut (ja sananlaskunkaltaiset ilmaukset) ovat 
yleensä kasvattajan omassa lapsuudessaan omaksumia, heijastaa muisteluaineiston kasvatuspuhe aiempien kasvattajien puhetta. 1900 luvun alkua koskevan kirjoitettu muistelu sisältää siten suomenkielisen väestön kasvatuspuheessa käyttämiä sananlaskuja ainakin 1800 luvun puolivälistä lähtien. Muistelukerronnalla olen tavoittanut sananlaskuja käyttävän kasvatuksellisen puheen toteutumisen kuvauksia.

\section{MENETELMÄN JA TUTKIMUKSEN YHTEYS ASKEL ASKELEELTA}

Kuten Ilkka Niiniluoto $(1994,41)$ toteaa, tieteellinen tutkimus on tutkijan ja tutkimuskohteen välistä vuorovaikutusta, jonka päämääränä on saavuttaa kohteesta uutta tietoa huomioiden, että kunkin aikakauden tieteellinen tieto on aina enemmän tai vähemmän sidoksissa ajallisesti muuttuviin ajattelutapoihin. Nykyisyys tuottaa itselleen aina oman menneisyytensä. Ne perusteet, joista kuva menneisyydestä rakentuu, ovat jo itsessään menneisyyden määräämiä.

Jos tiede tutkimusmenetelmineen käsitetään vain etsimiseksi, voi se kääntyä itseään vastaan. Etsiä voi vain jotakin, jonka tietää tai olettaa jo olevan olemassa. Tutkimusmenetelmistä Juha Varto $(1995,95)$ toteaa: "Tieteelliselle tutkimukselle ei ole olemassa sellaista metodia tai muuta välinettä, joka olisi valmiina olemassa ennen tutkimusta" ja "Menetelmä voi tulla ilmeiseksi vain siinä, kun se osoittaa ottavansa haltuun sen alueen, jota sen on tutkiminen".

Tutkimuksen tavoitteet kiteytyvät tutkimusongelmissa, joihin vastaaminen on pakottanut pohtimaan erilaisia menetelmällisiä ratkaisuja. Tutkimusmenetelmänä näen sisällönanalyysin ensisijaisesti ryppäänä menetelmiä, joista sisällönerittely on yksi vaihe. Sisällönanalyysin lisäarvo sisällönerittelyyn nähden on pohdinnassa, johtopäätöksissä ja mahdollisuudessa käyttää tutkimuksen eri vaiheiden edellyttämiä menetelmiä.

\section{TutKIMUSONGELMAT}

Tutkimuksen pääongelma kuuluu: "toteutuuko kasvatuspuheen sananlaskujen yhteydessä indoktrinatiivinen kasvatus?" Verbi indoktrinoida tarkoittaa iskostamista. Indoktrinaatiossa on aina kyse negatiivisesta kasvatuksesta tai ei-kasvatuksesta. Tutkimuksessa käsittelen indoktrinaatiota ennen kaikkea aidon kasvatuksen vastaisena vaikutustapana. Toinen ongelma keskittyy sananlaskujen tulkintaan, "miten merkitykset siirtyvät käytettäessä sananlaskuja?” Arkiset lausahdukset, kuten sananlaskut ja sanat siirtävät merkityksiä myös tapahtumissa, joita emme koe oppimistilanteiksi.

Kolmas tutkimusongelma on "mihin säädökset olivat ohjanneet kasvatusta aikana, jolloin kasvattajat olivat saaneet sananlaskut oman puheensa elementeiksi?" Säädöksillä tarkoitan lakien ja asetusten lisäksi hallitsijan muita määräyksiä, kirjeitä ja julistuksia. Neljännessä tutkimusongelmassa hain vastausta kysymyksiin "mihin 
muistelija koki lapsena tulleensa sananlaskuilla kasvatetuksi? Kenen puhetta kasvatuspuheen sananlaskut ovat olleet?"

Voidakseni vastata ensimmäisenä esittämääni ongelmaan, oli haettava menetelmä ja vastaus muihin kolmeen. Kahteen jälkimmäisen kysymykseen hain vastauksia elämäntarinoista ja säädöksistä. Lähestymistapaani liittyy tutkittavan ilmiön kokonaisuuden ymmärtäminen. Kahteen ensimmäiseen - vaikka käsittelyssä viimeiseen - tutkimuksen kannalta keskeiseen ongelmaan sovelsin teoreettis-käsitteellistä lähestymistapaa. Tutkimuksen eteneminen oli kulkemista, jossa askel kerrallaan siirryin kohti tutkimuksellisten ongelmien vastauksia kohti.

\section{Askeleet TIETEenaloitTAin}

Ottaakseni folkloristisen askeleen tarvitsin tietoa, mitä kasvatustavoitteita (merkityksiä ja tulkintoja) kuulijat ovat sananlaskuille antaneet. Neljännen tutkimusongelman lähtökohtaoletuksia ovat olleet ensiksikin, että sananlaskut ovat olleet osa kasvatuspuhetta ja toiseksi, että sananlaskujen vaikutus oli suuri erityisesti kirjoittamattoman tiedon aikakaudella. Tutkimusmenetelminä ovat laadullinen sisällönerittely, merkitysten ryhmittely ja teemoittelu.

Kasvatushistoriallisen askeleen kuluessa oli tarkasteltavan aikakauden käytänteitä legitimoivaa ja taustoittavaa ongelmaa varten selvitettävä, mitkä olivat 1900 luvun alun kotikasvatukseen vaikuttaneiden säädösten keskeiset kasvatussisällöt. Kolmannen ongelman lähtökohtaoletuksia ovat olleet kasvatuskäsitysten ja kasvatuksen päämäärien muutoksen hitaus sekä sukupolven ylittävään kasvatuspuheeseen sisältyvä aikaisempia kasvatustavoitteita säilyttävä ja ylläpitävä piirre. Lähtökohtana pidän myös oletusta, että autonomian ajalla voimassa olleet säädökset legitimoivat ei-institutionalisoidun kasvatuksen olemassaolon sekä virallisesti tunnustetun lasten kasvatuksen ja hoidon keskeiset sisältötavoitteet. Menetelminä ovat laadullinen sisällönerittely, sisältöjen ryhmittely ja teemoittelu.

Filosofisen askeleen otin toisen tutkimusongelman parissa, kun oli selitettävä ja kuvattava merkitysten siirtyminen. Tarkastellakseni sananlaskulle annetun merkityksen muuttumista laadin metaforateorioihin pohjautuvan mallin. Lähtökohtaoletuksia ovat olleet sananlaskun ja metaforan toiminnan samankaltaisuus sekä se, että ne kumpikin voivat saada sekä kirjaimellisen että vertauskuvallisen tulkinnan. Menetelminä ovat teoreettis-käsitteellinen lähestymistapa, metaforateoriat sekä mallintaminen, jonka perustin mahdollisten maailmojen semantiikkaan.

Kasvatusfilosofinen askel on ollut keskeisin. Edeltäviin kysymyksiin saatujen vastausten perusteella on ollut mahdollista tarkastella sitä, toteutuuko kasvatuspuheen sananlaskujen yhteydessä indoktrinatiivinen kasvatus. Lähtökohtaoletuksia ovat olleet ensinnäkin se, että kasvatus ei ole sama asia kuin indoktrinaatio. Toinen lähtökohtaoletus liittyy kielen vaikutukseen ajatteluun ja maailmankuvaan. Kolmas lähtökohtaoletus on, että tulkintaan vaikuttaa kuulijan kyky ymmärtää kieltä. Menetelminä ovat teoreettis-käsitteellinen tarkastelu, aidon kasvatuksen subteuttaminen indoktrinaa- 
Liisa Granbom-Herranen: Menetelmät monitieteellisen tutkimuksen haasteena

tion tunnusmerkistöön sekä argumentointi edeltävien kysymysten käsittelyä hyödyntäen.

\section{MONITIETEELLISYYS ON MAHDOLLISUUS}

Vaikka monitieteellisyys on jo vakiinnuttanut asemansa tutkimuksen parissa, on monitieteellisyyden ja poikkitieteellisyyden ero häilyvä. Esimerkkitutkimuksessa on kyse yhden viitekehyksen luomisesta ja pyrkimyksestä käsitteistön yhdenmukaisuuteen. Osa tämän tutkimuksen keskeisistä käsitteistä kuuluu ensisijaisesti kasvatustieteeseen kuten kasvatus ja indoktrinaatio, osa folkloristiikkaan kuten sananlasku. Keskeisessä käsitteessä kasvatuspuhe korostuu kasvatuksen ja perinteen yhteys arkikielessä. Se perustuu folkloristi Charles Briggsin termiin pedagogical discourse, jota hän käyttää merkityksessä kasvatuksellinen vuorovaikutus (ks. esim. Briggs 1985, 795; 1988, 22, 104). Kyse on puheesta, joka tapahtuu kasvatuksellisessa viitekehyksessä. Tällaisen kasvatuksellisen viitekehityksen puitteissa käytetystä puheesta käytän nimitystä kasvatuspuhe, englanniksi pedagogical speech.

Jos olettaisin sananlaskulla olevan universaalin ja muuttumattoman merkityksen, olisi lähtökohtanani ollut sananlaskun yleismerkitys (esim. Norrick 1985, 109-117). Näin ei kuitenkaan ole ollut, vaan olen hakenut sananlaskulle tulkintaa kuulijan kautta. Sananlaskun merkityksen siirtymän selittämiseksi luomani malli pohjautuu filosofian metaforakäsitteeseen, joka perustuu professorien Jaakko Hintikan ja Gabriel Sandun (1994) mahdollisten maailmojen semantiikkaan tukeutuvaan malliin. Tässä metaforamallissa on kyse ennen kaikkea tavasta, jolla ilmaisun referenssi, viittauksellisuus, määritellään muuttuvissa olosuhteissa. Lisäksi monet tutkimuksen kannalta merkitykselliset käsitteet ovat varsin monen tieteenalan käsitteistöön kuuluvia kuten esimerkiksi rahvas, ruokakunta, perhe ja koti. (Granbom-Herranen 2008, 18-19.) Mikäli kyse olisi ollut poikkitieteellisestä lähestymistavasta, olisin pyrkinyt lähestymään tutkimuskohdetta useamman kuin yhden tieteenalan paradigmasta käsin. Tulkitsen monitieteellisyyden ja poikkitieteellisyyden lähestymistavan välisen eron toisin kuin esimerkiksi Huumo, Laitinen ja Paloposki $(2004,12)$ esittämässään määrittelyssä, jossa nimenomaan poikkitieteellisyys luo yhden viitekehyksen ja siinä pyritään käsitteistön yhdenmukaisuuteen. Monitieteellisyyden he näkevät monen tieteenalan paradigmoja käyttävänä lähestymistapana. Heidän jaottelussaan tutkimukseni suuntautuisi ennemminkin poikki- kuin monitieteelliseen ongelman ratkaisuun.

Tutkimuksen keskeinen tieteenaloja yhdistävä tekijä on institutionalisoitumattoman, arjessa tapahtuneen lasten kasvatuksen tutkimus. Nykyistä käsitteistöä käyttäen kyse on lapsuudenaikaisesta kotikasvatuksesta. Tutkimus perustuu yhtäältä kokemusperäiseen empiiriseen aineistoon ja asiakirjoihin sekä toisaalta teoreettis-käsitteelliseen tarkasteluun. Kerronnallisena aineistona on Suomalaisen Kirjallisuuden Seuran kansanrunousarkiston kokoelmista kokoelmat Perinne elämässäni -kilpakirjoitus vuodelta 1985 sekä Karjalaiset elämäntarinat ajalta 1983-84. Ne sisältävät 
yli tuhat elämäntarinaa ja niissä kerronta on lähinnä kirjoitettua muistelupuhetta. Kokoelmista olen hakenut ne säädökset, joissa käsitellään vanhemmuutta ja erityisesti lasten (alle 15 vuotiaiden tai alaikäisten) elämää ja elinehtoja. Säädöksiä löytyy lähes 800, joista parinsadan voidaan katsoa kohdistuvan institutionalisoimattoman kasvatuksen tavoitteisiin. Elämäntarinat yhdessä säädösten kanssa mahdollistavat kasvatuksen totutuksen ja julkisten odotusten suhteen poh dinnan.

Kasvatushistoriallisena haasteena ovat olleet tavallisen ihmisen jokapäiväiseen elämään liittyvän kasvatuspuheen sananlaskut merkityksineen. Aineistot sijoittuvat autonomian aikaan ja aikaan ennen toista maailmansotaa. Säädösten kautta olen luonut katsauksen julkiseen käsitykseen siitä, mitä ruokakunnan puitteissa tapahtuneelta lasten kasvatukselta odotettiin 1800 luvulta 1900 luvun alkuun. Institutionaalisen ja ensisijaisesti asiakirjoihin perustuvan kasvatuksen historian tutkimuksesta poiketen aineistona on kirjoitettu muistelukerronta.

Tämä pohdinta aidon kasvatuksen ja negatiivisen kasvatuksen suhteesta kiinnittyy kasvatusfilosofiaan. Aito kasvatus on autonomiseksi ihmiseksi kasvamisen ohjaamista ja tukemista.

Yksi indoktrinaation ja aidon kasvattamisen keskeisistä eroista onkin juuri valmius olevan ja opetettavan arviointiin. (Granbom-Herranen 2008, 31.) Negatiivisen kasvattamisen muodoista kiinnostukseni kohteena on ollut indoktrinaation mahdollisuus sananlaskuille annetuissa merkityksissä. Folkloristiikan sananlaskututkimuksen kannalta tämän tutkimuksen keskeinen haaste on ollut sananlaskujen tarkastelukontekstissaan. Kontekstikeskeisyys antaa mahdollisuuden tarkastella kuulijan tulkintaa sananlaskun sisällöstä ja merkityksestä. Tarkastellessani sananlaskupuheen tavoitetta ei lähtökohtanani ole ollut sananlaskun oletettu yleismerkitys.

Filosofiaan tutkimus kiinnittyy metaforaan liittyvien pohdintojen kautta. Soveltamalla mahdollisiin maailmoihin perustuvaa metaforamallia voidaan arjen ympäristön ja sen muutoksen vaikutus tehdä ymmärrettäväksi ennen kaikkea kasvatuspuheen sananlaskun merkitykselle, mutta myös kasvatustapahtumalle sinänsä. Arki ja kasvatus ovat aina kiinteässä yhteydessä kulloisenkin aikakauden yhteiskunnalliseen sosiokulttuuriseen ja sosioekonomiseen elämään.

\section{SISÄLLÖNANALYYSI ESIMERKKINÄ OLEVASSA MONITIETEELLISESSÄ TUTKI- MUKSESSA}

Tutkimus perustuu yhtäältä kokemusperäiseen empiiriseen aineistoon ja toisaalta ajattelun kautta luotuun teoreettis-käsitteelliseen tarkasteluun. Tutkimuksen ensimmäinen käytännön vaihe on ollut aineiston valinta. Alustavana tutkimuksenani toimi sananlaskuja käyttöyhteydessään tarkastellut folkloristiikan pro gradu -tutkielma (Granbom-Herranen 2004).

Koska tutkimuksessa käyttämäni käsitteet ovat varsin monen tieteenalan käsitteistöön kuuluvia, olen käsitteitä määritellessäni pyrkinyt lukijan kannalta riittävään selvyyteen. Tämä käsitteiden määrittely liittyy myös sisällönanalyysissä seuraavaan 
vaiheeseen, perinnelajianalyysiin, jossa olennaista on ollut sananlaskujen tunnistaminen kerronnallisesta yhteydestään.

Sisällön erittely, merkitysten ja sisältöjen ryhmittely sekä teemoitus koskevat niin sananlaskuaineistoa kuin säädöksiäkin. Jotta sananlaskujen sisältämiä ja lapsen ymmärtämiä kasvatustavoitteita voi verrata julkisiin odotuksiin, on ne ensin aineistosta löydyttävä.

Oma vaiheensa sisällönanalyysissä on aikakauden kontekstin kuvaaminen. Tässä tutkimuksessa keskeisiä ilmiöitä ovat olleet suomenkieli ja lapsuus kasvattajien omat, autonomian aikaiset kasvutavoitteet huomioiden. Tarkasteltava väestön osa, suomenkielinen rahvas, oli autonomian ajan Suomessa enemmistönä, mutta sen elämää joudutaan kartoittamaan vähemmistötutkimuksen keinoin.

Teoreettis-käsitteellinen merkityksen muotoutumisen ja siirtymisen mallintaminen perustuu sananlaskun ja metaforan toiminnalliseen samankaltaisuuteen. Apuna on ollut mahdollisten maailmojen semantiikkaan perustuva metaforamalli. Aidon kasvatus ja indoktrinaation pohdinta on ollut systemaattista analyysiä. Tässä apuna on ollut negatiivisen kasvatustapahtuman tunnusmerkistö.

Jotta sisällönanalyysi voi olla tutkimusmenetelmä, siihen liittyvät kiinteänä osana johtopäätökset, pohdinta ja kritiikki.

\section{Aineistojen lukeminen, AnAlysointi ja RYhmittely}

Ensimmäiseen lukuvaiheeseen, selauslukuvaiheeseen, sisältyivät kokonaisuudessaan Perinne elämässäni -kilpakirjoitus (1985) sekä Karjalaiset elämäntarinat (1983-84). Keskittäessäni tarkastelun sananlaskujen käyttötilanteeseen, on kohteena oleva episodi ollut hyvinkin lyhyt hetki muistelijan elämässä. En kyseenalaistanut kerrottua, eikä minulta kysytty, hyväksynkö tapahtumat vai en tai koenko ne oikeina vai väärinä.

Selauslukuvaiheessa poimin aineistosta kaikki ne elämäntarinoiden jaksot, joihin sisältyi sananlasku tai sananlaskun kaltainen ilmaisu. Lukiessani Perinne elämässäni kilpakirjoituksen vastauksia, totesin aihepiirien Koti ja suku ja Sukupuoliroolit ja kasvatus avioliittoon sisältävän tietoa kasvatuksesta ja sananlaskuista, joten keskityin niihin. Karjalaiset elämäkerrat keruun muistelut olivat puolestaan kokonaisuuksia, eivät erillisiä kysymyksiä vastauksineen. Lukeminen oli aluksi lähinnä uteliasta tutustumista kertojien elämään ja elämänpiiriin. Tällä ensimmäisellä lukukerralla poimin Perinne elämässäni- ja Karjalaiset elämäkerrat keruista kaikki ne elämäntarinoiden jaksot, joihin sisältyi sananlasku tai sananlaskun kaltainen ilmaisu. Muistelujen lukemisen sisällön erittelyssä ensimmäinen vaihe on ollut lähinnä perinnelajianalyysiä, johon on kuulunut ensinnäkin sananlaskujen tunnistaminen tekstiyhteydestä ja toisaalta sananlaskuihin liittyvien kontekstitietojen kokoaminen tutkimusaineistoksi. Sananlaskun tunnusmerkistön pohtiminen on ollut rupeama sinänsä.

Seuraavalla lukukierroksella tutustuin entistä tarkemmin elämäntarinoihin. Tällöin poimin tekstit, joissa sananlaskujen käyttö liittyi lapsuuteen tai muistelija liitti 
ne kasvatukselliseen lapsuuden tapahtumaan tai tilanteeseen kertojan ollessa ensisijaisesti kuulijan roolissa. Tarkistuksena käytin akateemikko Matti Kuusen sekä Kansanrunousarkiston henkilökunnan kokoelmiin jo aiemmin tekemiä merkintöjä ja luettelointeja. Samalla rajasin kertojat syntymävuoden mukaan tavoitteenani painottaa tarkastelu ensisijaisesti suullisen tiedon aikaan. Ennen vuotta 1930 syntyneiden vanhemmat ja isovanhemmat ovat kasvaneet sääty-yhteiskunnassa vallinneen yhtenäiskulttuurin vaikutuksessa ja muistelijoiden lapsuus sijoittuu aikaan ennen maailmansotaa. Sananlasku tulkintoineen sekä käyttökonteksti muodostavat tarkasteltavan kokonaisuuden, analyysiyksikön. Tähän kuuluu vain teksteissä ilmaistu, eli sananlaskujen tulkinnassa en ole yrittänyt tulkita muisteltua enkä ole tukeutunut sananlaskuille annettuihin yleistulkintoihin.

Tarkasteltavat säädökset kohdistuvat muisteluaineistoa pidempään ajanjaksoon ja varhaisempaan aikakauteen. Säädökset eivät kerro toteutuksesta, mutta niiden voi tulkita antavan kuvan poliittisesti ja taloudellisesti vaikutusvaltaisten ryhmien asettamista odotuksista ja pyrkimyksistä. Säädöksiin paneutuminen on ollut samankaltainen prosessi kuin kerronnallisen aineiston yhteydessä. Selauslukuvaihe on kattanut säädökset Talonpoikainlaista vuodelta 1442 itsenäisen Suomen valtion muodostumiseen, vuoteen 1917. Säädösten valikointi tarkasteluun on ollut kokoelmien läpikäyntiä, tarkistuksena vielä kokoelmien sisältämien asiasanarekistereiden avulla. Säädösten luennassa sisällön erittelyn yksikkönä on lausuman sana sekä kyseisen säädöksen tarkoitus.

Löydetyt säädökset ovat johdattaneet eteenpäin lapsen elämää sivuaviin käsitteisiin ja niihin liittyviin säädöksiin, kuten esimerkiksi rippikoulua, alaikäisyyttä, vaivaishoitoa, irtolaisuutta ja vankeinhoitoa käsittelevään ohjeistukseen. Säädös ja asetuskokoelmista olen hakenut lait ja asetukset, hallitsijan julistukset ja kirjeet, jotka käsittelevät vanhemmuutta ja erityisesti lasten (alle 15 vuotiaiden tai alaikäisten) elämää ja elinehtoja.

Lukuprosessien jälkeen keskityin tiedon taulukointiin ja merkitysten ryhmittelyyn. Elämäntarina-aineiston ryhmittely on alkanut hakemalla kasvatuspuheeseen sisältyvien sananlaskujen tavoite muisteluepisodeista. Säädöksien ryhmittelyn ensimmäinen vaihe puolestaan on ollut määrittää se, mihin lapsen elämän alueeseen kyseisellä säädöksellä on pyritty vaikuttamaan.

\section{MALlintaminen}

Sananlaskujen ja metaforien toiminta on keskenään samankaltaista. Sananlaskujen vaikuttavuuden tarkastelussa olen tukeutunut metaforateorioihin. Pelkkä vertaus tai samanlaisuus ei sananlaskun yhteydessä ole riittävä perusta merkityksen määrittämiselle, kuten on aristoteelista (Fogelin 1988) tai interaktioteorian mukaista metaforatulkintaa (Black 1981) käytettäessä. Intentioteoria ei useinkaan ole käyttökelpoinen selittäjä (Searle 1981), sillä puhujan intentio ei yleensä selviä. Kirjaimellinen tulkinta puolestaan ei ole riittävä perusta (Davidson 1981). Olen päätynyt soveltamaan Hin- 
tikan ja Sandun (1994) metaforatulkintaa, jonka avulla voidaan tarkastelussa yhdistää sananlaskut ja niiden tulkinta sekä liittää niihin sananlaskuja käyttävä kasvatuspuhe.

Sananlaskun merkityksen siirtymää kuvaava malli toteutuu mahdollisten maailmojen semantiikkaan perustuvan metaforamallin pohjalta. Mallintaminen toimii työkaluna pohtiessani aidon kasvatuksen ja indoktrinaation toteutumista sananlaskuja käyttävässä kasvatuspuheessa. Mallintamalla osoitan, että ilmaisun merkityksen tulkinta ei voi olla ulkoapäin annettu, kuten on käytettäessä sananlaskujen oletettua yleismerkitystä. Malli todentaa, että jossakin tilassa (aika ja paikka) sananlaskulle annettu merkitys voi muuttua lausuman siirtyessä toiseen tilaan.

\section{SySTEMAATTINEN ANALYYSI}

Tutkimuksen keskeisimmän kysymyksen "Toteutuuko kasvatuspuheen sananlaskujen yhteydessä indoktrinatiivinen kasvatus?" käsittely perustuu luomaani malliin. Käytän sitä pohtiessani indoktrinaation ja aidon kasvatuksen suhdetta kasvatuspuheen sananlaskuihin. Tämä on puolestaan edellyttänyt sekä aidon kasvatuksen olemuksen että indoktrinaation tunnusmerkistön tarkastelua.

Kuten sisällönanalyysi, ei systemaattinen analyysikaan ole mikään yksittäinen menetelmä. Kyseessä on prosessi, jossa ongelman ratkaisuun pyritään teorian sisältöön liittyvien seikkojen selventämisen kautta. Systemaattinen analyysi tukeutuu kielellisen ilmaisun esittämään ajatusmaailmaan, josta johdetaan ajatusrakenteen kannalta olennaiset ja alkuperäisen ajatuskokonaisuuden selkiyttämisen mahdollistavat ajatusrakennelmat.

\section{KRIITTISYYS}

Laadullisen tutkimuksen erityispiirteenä on se, että sekä tutkija että tutkittava ilmiö sijoittuvat jollakin tavoin jaettuun elämismaailmaan. Koska tällöin merkitysten luomat kokonaisuudet vaikuttavat väistämättä myös tutkijan toimintaan ja tekemiin tulkintoihin laadin vastineeni filosofi Juha Varton $(1992,36)$ esittämään haasteeseen. Haaste voidaan kiteyttää seuraaviksi, jokaista laadullista tutkimusta koskeviksi edellytyksiksi:

1) Tutkijan esiymmärryksen erittely.

2) Tutkimuksen lähtökohtaoletusten tarkastelu, johon voi kuulua esimerkiksi tutkimuskohteen ontologinen erittely, tutkijan mielenkiintoprofiilin tunnistaminen sekä tutkimuksen perustana olevan ihmiskäsityksen artikulointi.

3) Tutkimuskohteen luonnetta koskevat oletukset ja arvaukset.

Oman vastineeni olen kirjannut tutkimukseeni (ks. Granbom-Herranen 2008, 48-51).

Keskeinen säädösten käyttämistä aineistona koskeva kritiikki kohdistuu säädösten ja tapahtumien suhteeseen. Kun kyse on tutkimuksesta, jossa empiirinen muistelu- 
aineisto ei ole tutkijan itsensä keräämää, on taustaoletuksena, että kerääjien tavoitteena on ollut saada koottua mahdollisimman kattava aineisto.

Muistitietohistorian kritiikki on keskittynyt muistin rajallisuuteen sekä kulttuuristen tekijöiden vaikutukseen. Muita kritiikin kohteita ovat aineiston edustavuus suhteessa koko väestöön, kirjoittajien valikoituminen tai kertomusten todenperäisyys. Olennaista on nähdä, että kaikella muistellulla ja kirjoitetulla puheella on oma syntykontekstinsa.

\section{TUTKIMUKSEN JA TUTKIMUSMETODIN VALINNAN PERUSTA}

Monitieteisen tutkimuskokonaisuuden kannalta pidän ensisijaisena sitä, että on olemassa tutkimustehtävä, jonka ratkaisu joko ei ole mahdollista yhden tieteenalan puitteissa. Kaikissa tapauksissa monitieteisyyden on tuotava jotakin lisäarvoa sekä tutkimuksen kulkuun että sillä saavutettaviin tuloksiin. Monitieteinen tutkimusongelma kiteytyy harvoin vain yhteen tai kahteen kysymykseen.

Kuten kaikissa tutkimuksissa, myös monitieteisessä lähestymistavassa tutkimusmenetelmien tulee olla mielekkäitä tehtävän kannalta. Hyötynä voi olla uuden lähestymistavan löytyminen. Kenties jonkin tieteenalan kannalta epätyypillisen menetelmän valinta tukee uuden tiedon löytymistä. Sama pätee aineistoihin. On palon aineistoja, jotka jollakin tieteenalalla ovat itsestään selvyys ja toisella lähes käyttämätön varanto. Arkistoissa olevat elämäntarinat ja kuvaukset arkisista toimista tarjoavat edelleen esimerkiksi kasvatuksen tutkijoille uusia mahdollisia näkökulmia. Aineistojen ja menetelmien kannalta monitieteellisyys on haastavuudessaan mahdollisuus.

Tutkijalla on aina keskeinen rooli tulkitsijana, oli sitten kyse mistä tutkimuksesta tahansa. Siksi pidän tärkeänä, että tutkija tunnistaa itsessään ja taustassaan olevat sidonnaisuudet. Tämä ei tarkoita, että sidonnaisuuksia ei saisi olla. Jokaisella niitä on, mutta kun tutkija ne tunnistaa, voi hän välttää ennakkoasenteidensa manifestoitumisen tutkimuksessa.

Kenties teknologiatieteissä on humanistisia tieteitä tavanomaisempaa pohtia tutkimuksen tuottamaa hyötyä. Jokaisesta tutkimuksesta on oltava hyötyä tutkimuksen taustavoimille. Tämä ei aina tarkoita suoraa taloudellista hyötyä. Tutkimustehtävän asettamisella on pyritty joko ratkaisemaan olemassa oleva ongelma tai tuottamaan uutta tietoa. Tässä esimerkkinä käyttämäni tutkimuksen

tuottama tieto on pyrkinyt lisäämään valmiuksia tunnistaa kasvatukseen ja opetukseen liittyviä piilomerkityksiä. Kotikasvatuksen tarkastelu on myös kannanottamista vanhemmuudesta käytävään keskusteluun. Tutkimus on osin tieteellistä perustutkimusta, joka mahdollistaa tuotettujen tietojen hyödyntämisen niin kasvatustieteen, folkloristiikan kuin filosofiankin alalla. Tarkoitus on ollut joitakin itsestään selvyyksiä kyseenalaistamalla herättää lisäkysymyksiä ja mahdollistaa uusien näkemysten muotoutuminen. 
Liisa Granbom-Herranen: Menetelmät monitieteellisen tutkimuksen haasteena

\section{LÄHTEET}

Suomalaisen Kirjallisuuden Seuran kansanrunousarkisto

- Karjalaiset elämäkerrat vuosilta 1983-84 (KE84)

- Perinne elämässäni. Kalevalan jublavuoden kilpakirjoitus vuodelta 1985 (PE85)

\section{SÄÄDÖSKOKOELMAT}

6.8.1723 KONGL. MAIJ:SS FÖRNYADE STADGA OCH FÖRORDNING / Angående Tienstefolck och Legohion. Gifwen Stockholm i Rådkammaren den 6. Augusti 1723. Cum Gratia \& Privilegio S:ae R:ae Maj:tis. Sederholm./ uti Kongl. Boktryckeriet uplagdt/ hos Johan Henr. Werner, Directeur öfwer Boktryckerien i Riket.

HELLEMAA, LAHJA-IRENE \& JUSSILA, ANJA \& PARVIO, MARTTI (toim.) 1986: Kircko-Laki Ja Ordningi 1686. Näköispainos ja uudelleen ladottu laitos vuoden 1686 kirkkolain suomennoksesta. Helsinki: SKS.

MODÉE, R.G. (1742-1829). Utdrag utur alle ifrån den 7 Decemb. 1718 utkomne - till 1794 års slut. Publique Handlingar, Placater, Förordningar, Resolutioner och Publicationer I-XV. Stockholm.

KOIVUSALO, ESKO \& JUSSILA, RAIMO (toim.) 1984. Ruotsin Waldakunnan Laki 1734. Näköispainos. Porvoo: WSOY.

SAMLING AF DE I STORFURSTENDÖMET FINLAND gällande och intill år 1855 utkomne Författningar, hwilka ändra eller förklara landets allmänna Lag eller utwidga och närmare bestämma föreskrifterne i de ämnen densamma omfattar. På Hans Kejserliga Majestäts nådiga befallning, utgifwen af Deb för Finland tillförordnade Lag-Kommission. (Förra Delen 1538-1799. Helsingfors: J.C Frenckell \& Son, 1855; Senare Delen 1800-1854. Helsingfors: J.C Frenckell \& Son, 1855).

SAMLING AF DE TILL EFTERLEFNAD GÄLLANDE BREF, FÖRKLARINGAR OCH FÖREKSRIFTER, hwilka af Hans Kejserl. Maj:t, äfwensom ifrån Expeditionerne i Dess Senat för Stor-Furstendomet Finland blifwit utfärdade uti Justititiae-, Oeconomiae- och Politiae-Ärender. Från och med år 18091859. (1840-1862).

SAMLING AF PLACATER, FÖRORDNINGAR, MANIFESTER OCH PÅBUD, samt andre Allmänna handlingar, hwilka i Stor-Furstendomet Finland sedan 1808 års början ifrån trycket kommit. Åbo. 1821-1862.

SUOMEN SUURIRUHTINAANMAAN ASETUSKOKOELMA (Asetus-Kokoelma/ Asetus-Kokous) 1860-1917 sekä Suomen Asetuskokoelma 1917-.

TALONPOIKAIN LAKI. Kuningas Kristofferin maanlain (1442) suomennos Caloniuksen kopion mukaisesti. 2005. Helsinki: SKS. 
Liisa Granbom-Herranen: Menetelmät monitieteellisen tutkimuksen haasteena

\section{KIRJALlisUUS}

BLACK, MAX 1981: More About Metaphor. - Ortony, Andrew (toim.), Metaphor and thought. Cambridge: Cambridge University Press. [1980]

BRIGGS, CHARLES L. 1985: The Pragmatics of Proverb Performances in New Mexican Spanish. - American Anthropologist vol. 87.

BRIGGS, CHARLES L. 1988: Competence in Performance. The Creativity of Tradition in Mexicano Verbal Art. Philadelphia: University of Pennsylvania Press.

DAVIDSON, DONALD 1981: What Metaphors Mean. - Sacks, Sheldon (toim.), On Metaphor. Chicago (IL): The University of Chicago Press. [1979]

FOGELIN, ROBERT J. 1988: Figuratively Speaking. New Haven: Yale University Press.

GRANBOM-HERRANEN, LIISA 2004: Sananlaskujen käyttäjät ja käyttöyhteys. Sananlaskut käyttökontekstissaan 'Perinne elämässäni' kilpakirjoituksen aineistossa. [online] Helsingin yliopisto. < http://urn.fi/URN:NBN:fi-fe20051452 > [13.9.2010]

GRANBOM-HERRANEN, LIISA 2008: Sananlaskut kasvatuspuheessa-perinnettä, kasvatusta, indoktrinaatiota? [online] Jyväskylän yliopisto. <http://urn.fi/URN: ISBN:978-951-39-3111-7> [13.9.2010]

HINTIKKA, JAAKKO \& SANDU, GABRIEL 1994: Metaphor and Other Kinds of Nonliteral Meaning. - Hintikka, Jaakko (toim.), Aspects of Metaphor. Dordrecht: Kluwer Academic.

HUUMO, KATJA \& LAITINEN, LEA \& PALOPOSKI, OUTI 2004: Alkusanat. - Huumo, Katja \& Laitinen, Lea \& Paloposki, Outi (toim.), Yhteistä kieltä tekemässä. Näkökulmia suomen kirjakielen kehitykseen 1800 luvulla. Helsinki: SKS.

KALELA, JORMA 2000: Historiantutkimus ja historia. Helsinki: Gaudeamus.

KUUSI, MATTI 1954: Sananlaskut ja puheenparret. Helsinki: SKS.

NIINILUOTO, ILKKA 1994: Tiede ja tieteenfilosofia. - Niskanen, V.A. (toim.), Tieteellisten menetelmien perusteita ihmistieteissä. Opiskelijan opas. Helsingin yliopiston Lahden tutkimus ja koulutuskeskus.

NORRICK, N.R. 1985. How Proverbs Mean: Semantic Studies in English Proverbs, Berlin: Mouton.

PERTTULA, JUHA 1993: Fenomenologinen psykologia. Kokemuksen systemaattista tutkimusta. - Psykologia vol. 28 (4).

SATULEHTO, MARKKU 1992: Elämismaailma tieteiden perustana. Edmund Husserlin tieteen filosofia. Filosofisia tutkimuksia Tampereen yliopistosta vol 33.

SEARLE, JOHN R. 1981: Metaphor. - Ortony, Andrew (toim.), Metaphor and thought. Cambridge: Cambridge University. [1980]

ULJENS, MICHAEL 1989: Fenomenografi - forskning om uppfattningar. Lund: Studentlitteratur.

VARTO, JUHA 1992. Laadullisen tutkimuksen metodologia. Helsinki: Kirjayhtymä. VARTO, JUHA 1995: Fenomenologinen tieteen kritiikki. Tampereen yliopisto.

Liisa Granbom-Herranen on kasvatustieteen tohtori ja folkloristiikan maisteri, ja toimii tutkijana Jyväskylän yliopistossa. 